\title{
THE TAXONOMY OF MONOGENEAN GILL PARASITES FROM SCYLIORHINUS CANICULA AND RAIA CLAVATA AT PLYMOUTH
}

\author{
By Anne C. Coupland \\ Department of Zoology and Comparative Physiology, University of Birmingham
}

(Text-figs. I and 2)

During the course of some studies on the biology of monogenean gill parasites of the elasmobranchs Scyliorhinus canicula (L.) and Raia clavata (L.) at Plymouth, the results of which it is hoped to publish later, difficulties were met in the identification of the parasites. In the past, monogeneans from $S$. canicula have from time to time been referred to as species of Hexabothrium or Onchocotyle, and those from R. clavata as species of Onchocotyle, Rajonchocotyle, or Rajonchocotyloides.

The genus Hexabothrium is regarded as containing three species (Sproston, 1946): (I) H. canicula (Cerfontaine, I899) Price, I942; (2) H. appendiculatum (Kuhn, I829) Nordmann, I832; and (3) H. musteli (MacCallum, I93I) Price, 1942. Of these, H. musteli is clearly recognizable from the other two in that each of its two vaginae opens in the centre of some heavily cuticularized tissue from which radiate bands of similar tissue. I have confirmed that this distinction is valid by comparing preparations of $H$. musteli from Mustelus canis from Wood's Hole (kindly loaned to me by Dr J. S. Laurie) with Plymouth specimens of ' $H$. canicula' from the gills of Scyliorhinus canicula and ' $H$. appendiculatum' from the gills of Scyliorhinus stellaris. There were, however, no obvious differences between these last two species, and so further investigation was necessary.

Specimens of S. canicula and S. stellaris (syn. Scyllium catulus) landed over a total period of about 1o weeks, mainly in spring and summer in 1959, 1960, and I96I, were examined for gill parasites. Scyliorhinus canicula was brought in nearly every day, and $43 \%$ of a sample of over roo host specimens was found to be infested with monogenean parasites. S. stellaris was much more scarce; only eighteen specimens were landed, and these yielded four parasites, the infestation never exceeding one parasite per host fish.

The morphological features of the parasite from the gills of $S$. canicula agree very closely with those given by Cerfontaine (1899) in his description of Hexabothrium canicula (Cerfontaine, I899) Price, 1942 from the same host. This species was proposed by Cerfontaine to distinguish some parasites, which he collected from $S$. canicula, from a single specimen of what he regarded as another species Hexabothrium appendiculatum (Kuhn, I829) Nordmann, I832, 
which he collected from S. stellaris. In diagnosing his new species H. canicula, Cerfontaine made use of several characters (e.g. the form of the penis spines, the shape of the adhesive disk, and the relative sizes of the hooks of the disk), but, on close inspection of the diagnoses of the two species, only one character, namely, the shape of the penis spines, appears to be of possible significance. Of the penis spines of $H$. appendiculatum (syn. Acanthonchocotyle appendiculatum) Cerfontaine (1899, pp. 46I-2) stated 'Armature génitale constituée par un grand nombre de petits crochets. Ces crochets sont plus forts que dans l'espèce suivante (i.e. H. canicula); leur partie basilaire est plus grosse relativement à la pointe' and of those of $H$. canicula (syn. Acanthonchocotyle canicula) Cerfontaine said: 'Armature génitale formée d'un grand nombre de petits crochets. Ces chrochets sont plus faibles que dans l'espèce précédente, leur partie basilaire est moins nettement séparée de la pointe'. These penis spines were illustrated by Cerfontaine (1899, Pl. 19, Fig. 14). Thus the species $H$. canicula appears to have been erected mainly on the grounds that its penis spines were, according to Cerfontaine, 'weaker', and that the basal part of the spine was thought to be less clearly separated from its point than in those of the single specimen of $H$. appendiculatum used for comparison.

The penis spines of the gill parasites of the two species of Scyliorhinus caught at Plymouth were examined. From preparations of the animals mounted in sea water under a cover-slip it was found that in parasites from each of the two host species the numerous penis spines were arranged in a triangular area with the apex directed posteriorly. The spines varied in overall length from 4 to $\mathrm{I} 2 \mu$, and were arranged in a graded series with the smallest posteriorly and the largest anteriorly. An examination of well-pressed preparations of freshly dead parasites showed that the individual penis spines of ' $H$. canicula' were indistinguishable from those of ' $H$. appendiculatum' (Figs. I and 2). Moreover, no morphological differences of any kind, including all those that have been used previously to separate the various species of the Hexabothriidae (e.g. differences in lengths of vaginae, differences in positions of openings of vaginae) were found between the hexabothriids from the two different host species.

Apart from the comparison of the hexabothriids from $S$. canicula and $S$. stellaris made in the present study and that made by Cerfontaine (1899, pp. 46I-2), only Guberlet (1933) has made a corresponding study. He, however, interpreted Cerfontaine's diagnoses concerning the penis spines as being that $H$. canicula has a large number of spines which vary markedly in size, whilst $H$. appendiculatum has fewer spines which are of a uniform size. This does not appear to be an accurate translation of Cerfontaine's diagnoses, nor does it agree with Cerfontaine's illustration (1899, Pl. 19, fig. I4). Even so Guberlet found no difference between the parasites which he collected from the two species of Scyliorhinus, and he recorded only one species, $H$. canicula, from both $S$. canicula and S. stellaris. 
On morphological grounds then, the hexabothriid gill parasite from S. canicula, listed in the Plymouth Marine Fauna as Hexabothrium caniculae (Cerfontaine, 1899) Price, I942, must be declared a synonym of $H$. appendiculatum (Kuhn, I829) Nordmann, 1832. H. appendiculatum is thus not restricted to one host species. However, while most polyopisthocotylineans are strictly host specific (see Llewellyn, 1957), this lack of specificity is not unique: a similar situation is known for Plectanocotyle gurnardi, Diplozoon paradoxum, and Discocotyle sagittata.
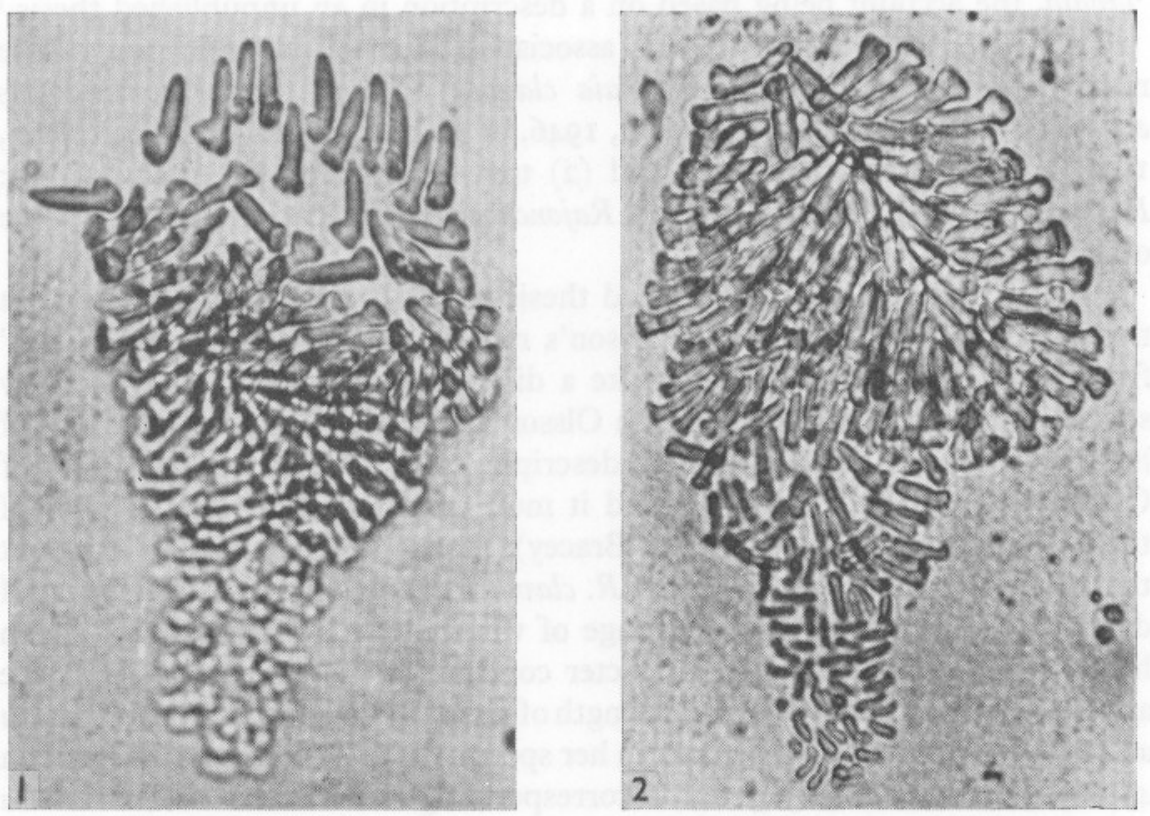

Figs. I and 2. A comparison of the penis spines of monogeneans from the gills of Scyliorhinus canicula (Fig. I) and S. stellaris (Fig. 2). (Macerated, unfixed, well-pressed specimens, photographed with $\times$ Ioo oil immersion objective.)

The first record of a monogenean from the gills of Raia clavata was that of Olsson (1876), who placed this parasite in a new species 'Onchocotyle emarginata' in order to distinguish it from what he regarded as three other species of monogeneans, one from the gills of each of three other elasmobranch species. Monogeneans from the gills of Raia clavata have been recorded subsequently as 'Onchocotyle emarginata' by Sonsino from Italy, and as ' $O$. appendiculata' by Baylis \& Jones (1933) from Plymouth. Later, one of the specimens collected by Baylis \& Jones was described in some detail by Price (1940), who identified the parasite as the species described from the same host by Olsson (1876), but placed it in a new genus Rajonchocotyloides. 
Sproston (1946) also collected monogeneans from the gills of Raia clavata at Plymouth, Roscoff, and Cardigan Bay, but, while following Price in referring them to Olsson's species, did not accept Price's new genus, and allocated the species to Cerfontaine's (1899) genus Rajonchocotyle. The same parasite was collected from Raia clavata at Plymouth by Dawes (1947), who, however, included the species in Price's genus Rajonchocotyloides.

In addition to describing her own specimens of Rajonchocotyle emarginata, Sproston (1946) also gave an account of what was thought to be a second species of Rajonchocotyle on the gills of Raja clavata, namely Rajonchocotyle lavata, the account being based on a description in an unpublished thesis. ${ }^{1}$

There are, then, two problems associated with the identification of the monogeneans from the gills of Raia clavata: (I) are they Rajonchocotyle emarginata (Olsson, I876) Sproston, 1946, or R. clavata Bracey (in Sproston, I946), or some other species? and (2) to which genus do they belong: Rajonchocotyle Cerfontaine, I899 or Rajonchocotyloides Price, 1940, or to some other genus?

I have consulted the unpublished thesis by P. Bracey, and it is apparent that although he was aware of Olsson's record of 'Onchocotyle emarginata' from Raia clavata, he did not make a direct comparison of his own 'new species' Rajonchocotyle clavata with Olsson's species. If Bracey's account of his $R$. clavata is compared with the descriptions by Price and by Sproston of Olsson's species $R$. emarginata (and it must be pointed out that neither of these descriptions was available to Bracey), then it becomes readily apparent that all but one of the characters of $R$. clavata regarded by Bracey as being of diagnostic value fall within the range of variability for $R$. emarginata given by Sproston. The remaining character concerns the $Y$-shaped hooks of the appendage: Price gave the over-all length of one of these hooks in $R$. emarginata as $40 \mu$; Sproston found the hooks in her specimens to be consistently between 47 and $48 \mu$; and Bracey gave the corresponding measurement in $R$. clavata as $45 \mu$. I have taken a sample of five parasites from the gills of Plymouth Raia clavata and allowed them to macerate in sea water for a day or two so that the softening of the surrounding tissues would permit the very resistant hooks to lie flat on a slide when under pressure from a cover-glass. After this treatment the ten hooks were found to have a mean length of $49 \mu$, with a range of from 44 to $53 \mu$. It is therefore considered that Bracey's use of the over-all length of these hooks as a specific character was without adequate foundation. Bracey also used as a diagnostic character the length of the ventral arm of the hook, which he found to be $22.7 \mu$, but I have found this length also to vary between 20 and $25 \mu$, so that this too seems inadequate for specific diagnosis. A third distinguishing feature used by Bracey was the presence of what was described as a 'flange' between the arms of the Y-shaped hook in Rajonchocotyle clavata, and its absence in R. emarginata, but I have found an irregular

${ }^{1}$ Univ. Coll. Wales, Aberystwyth. M.Sc. Thesis. I940. 
projection between the arms of the hooks in some, but not all, of the specimens which I have collected from Raia clavata, and which in all other respects are indistinguishable from Rajonchocotyle emarginata. Finally, the material studied by Bracey came from the same host (Raia clavata), and from the same locality (Cardigan Bay), as some of the specimens studied by Sproston, who regarded all of her specimens as belonging to Rajonchocotyle emarginata. It is concluded therefore that $R$. clavata Bracey (in Sproston, I946) must be regarded as a synonym of $R$. emarginata (Olsson, I876) Sproston, 1946.

With regard to the generic allocation of the monogeneans from Raia clavata, Price (1940) erected a new genus Rajonchocotyloides for them on the single character of the intrusion of the vitellaria into the haptoral appendix. However, Sproston (1946, p. 370) has described the variability with age of this character in her specimens of Rajonchocotyle emarginata, and I have confirmed that the same phenomenon is present in my specimens. Moreover, in two large ( $13 \mathrm{~mm}$. long) specimens of $R$. batis collected by Rees \& Llewellyn (I94I), I have observed that the appendix contains vitelline follicles in the one, but not in the other. Thus, with regard to the so-called generic character in question, there is, in addition to a variation with age in one species, an intraspecific variation in fully grown specimens of another species. It is concluded therefore, that at least in monogeneans from the gills of pleurotrematans, the use as a generic character of the presence or absence of vitelline follicles in the haptoral appendix is invalid, and that Sproston's relegation of Rajonchocotyloides Price, I940 to synonymy with Rajonchocotyle Cerfontaine I899 was perfectly justified.

The proper taxonomic designation of the monogenean from the gills of Raia clavata at Plymouth is therefore Rajonchocotyle emarginata (Olsson, I876) Sproston, I946.

I wish to thank the Director and Staff of the Laboratory of the Marine Biological Association for the facilities provided whilst working at Plymouth. I am very grateful also to Dr J. Llewellyn for his advice during the preparation of this paper.

\section{SUMMARY}

The monogenean gill parasites from Scyliorhinus canicula and S. stellaris at Plymouth have been found to be identical; their proper taxonomic designation is Hexabothrium appendiculatum (Kuhn, I829) Nordmann, I832. H. canicula (Cerfontaine, I899) Price, 1942 is a synonym of H. appendiculatum.

The hexabothriid collected from Raia clavata at Plymouth has been identified as Rajonchocotyle emarginata (Olsson, I876) Sproston, I946, and $R$. clavata Bracey (in Sproston, I946) has been shown to be synonymous with it. 


\section{REFERENCES}

BAYLIS, H. A. \& JoNES, E. I., I933. Records of parasitic worms from marine fishes at Plymouth. F. mar. biol. Ass. U.K., Vol. 18, pp. 627-34.

Dawes, B., 1947. The Trematoda of British Fishes. London: Ray Society.

Cerfontaine, P., I899. Contribution a l'étude des Octocotylidés. V. Les Onchocotylinae. Arch. Biol., Paris, T. 16, pp. 345-478.

GuBERLET, J. E., 1933. Notes on some Onchocotylinae from Naples with a description of a new species. Publ. Sta. Zool. Napoli, Vol. I2, pp. 323-36.

Llewellyn, J., I957. Host specificity in monogenetic trematodes. In: First Symposium on Host Specificity among Parasites of Vetrebrates, pp. I9I-2I2. Neuchâtel.

Olsson, P. 1876. Bidrag till scandinaviens helminthfauna. K. svenska Vetensk. Akad. Handl., N.F., Bd. I4, pp. I-35.

Price, E. W., I940. A redescription of Onchocotyle emarginata Olsson, I876, (Trematoda: Monogenea). Proc. helminth. Soc. Wash., Vol. 7, pp. 76-8.

ReEs, G. \& Llewellyn, J. I94I. A record of the trematode and cestodes parasites of fishes from the Porcupine Bank, Irish Atlantic Slope and Irish Sea. Parasitology, Vol. 33, , pp. 390-6.

Sproston, N. G., 1946. A synopsis of the monogenetic trematodes. Trans. zool. Soc. Lond., Vol. 25, pp. 185-600. 